\title{
Factor Affecting Birth Weight of Mehsana Goat Kid at Organized Farm
}

\author{
J.V. Patel*, A.K. Srivastava, H.D. Chauhan, J.P. Gupta, Y.M. Gami, \\ V.K. Patel, M.P. Madhavatar and N.K. Thakkar \\ College of Veterinary Science and Animal Husbandry, Sardarkrushinagar Dantiwada \\ Agriculture University, Gujarat, India \\ *Corresponding author
}

\section{A B S T R A C T}

\section{Keywords}

Birth weight, Mehsana, Goat, Kids, Season, Sex

Article Info

Accepted:

15 January 2019

Available Online:

10 February 2019
Data on birth weight pertaining to 373 Mehsana kids for a period spread over 7 year (from 2011 to 2017) maintained at organised farm were utilized to study the various factors affecting it. On the basis of date of birth of kids, data were divided in to 3 different seasons and 7 periods (year). Effects of sex of kids as well as type of birth on birth weight were also assessed using least squares analysis. The average birth weight of Mehsana kids was $2.555 \pm 0.043 \mathrm{~kg}$. The male $(\mathrm{n}=180)$ Mehsana kids showed significantly $(\mathrm{P}<0.01)$ higher birth weight than female $(n=193)$. This may be due to the effect of male sex hormone, which influences grow faster during pre-natal development. The birth weight of Mehsana kids born as single $(n=263) 2.689 \pm 0.042 \mathrm{~kg}$ were significantly heavier than those born as twins $(n=110) 2.4107 \pm 0.064 \mathrm{~kg}$ which is obvious because in multiple births the nutrients available from the mother are shared by twin kids. The effects of season on birth weight of Mehsana kids were estimated to be non-significant. The year of birth also had significant $(\mathrm{P}<0.01)$ effect on birth weight.

\section{Introduction}

Goat (Capra hircus) was the earliest ruminant domesticated around 9000 to 7000 B.C. Goat is also known as "poor man's cow" as the name given by Father of Nation, Mahatma Gandhi. Goat contribution is being the source of revenue for livestock-keepers, especially for family unit with minimum land resources and for landless labours. India possesses the second-largest goat population in the world having 135.17 million goats, but their population has declined by $3.82 \%$ over the previous census (Anonymous, 2012). The goat diversity in Gujarat is reflected in the form of five distinct goat breeds namely Mehsana, Surti, Gohilwadi, Zalawadi and Kutchi. The Mehsana goat is a dual purpose breed of domestic goat which is raised primarily for meat and milk production. Birth weight is an economic indicator for any livestock production purpose. There is a positive correlation in birth weight and further increasing of the live weight of animals (Roy et al., 1989). Studies of various authors show that birth weight is influenced by sex, type of birth, season of birth, maternal age and more (Supakorn and Pralomkarn, 2009; Bharathidhasan et al., 2009).The present work was undertaken to study the effect of season, 
sex of kid and type of birth on birth weight in mehsana goat kids under semi-intensive system at organised herd.

\section{Materials and Methods}

There were 373 Mehsana kids born between 2011 and 2017at the Goat section, Livestock Research Station, Sardarkrushinagar, Dantiwada, Gujarat. Geographically, the farm is located in North Gujarat at an altitude of 136 meters above the mean sea level. It lies at latitude of $24.35^{\circ}$ North and longitude of $72.59^{\circ}$ East. Annual rain fall is around 600 $\mathrm{mm}$ (Anonymous 2017). The climate of the farm is semi-arid in nature. Goats were maintained under semi-intensive system. In farm feeding done in two time in a day in morning feeding concentrate feeding (1\% of body weight) and green fodder and in evening feeding also provide green fodder. Feed provide to the kid half-moon shape Federer and 1.5 feet above the ground level. Grazing time of goat is around 8 hours. Clean adlibitum water is provide to kid. The type of birth was either single or twin and no triplets were noticed. The year was divided into 3 seasons viz., Summer (March-June), Monsoon (July-December), Winter (November-February) to study the effect of season on birth weight of kids. The data were subjected to least-square analysis (Harvey 1987). The variation in Mehsana goats due to sex, type of birth, year, season and month of births were analysed statistically (Snedecor and Cochran, 1994).

\section{Results and Discussion}

\section{Effect of sex of kid on birth weight}

Birth weight data of 373 Mehsana kids for a period spread over 7 year were tabulated according to the sex of kids to determine the effect of sex on birth weight (Table 1). The overall mean birth weight was $2.555 \pm 0.043$ $\mathrm{kg}$. The result pertaining to the average body weight at birth for male kids and female kids were $2.642 \pm 0.048 \mathrm{~kg}$ and $2.454 \pm 0.051 \mathrm{~kg}$, respectively. The statistical analysis revealed that sex had significant $(\mathrm{P}<0.01)$ effect on birth weight of kids. Banerjee and Jana (2010) also reported significant effect of sex on birth weights in Sirohi goat kids. Present findings corroborated to reports of Chawla et al., (1984), Sanchez et al., (1994), Tomar et al., (1997), Raza et al., (1998), Elabid (2008), Bharthidhasan et al., (2009), Bhusan (2012), Singh et al., (2013), Harikrishna et al., (2013) and jatet.al., (2018) This may be due to anabolic effect of male hormones (Hafez, 1962 and Chandra et al., 2009) which influences growth factor during pre-natal development.

\section{Effect of season on birth weight}

Table 1 revealed that maximum birth weight was $2.604 \pm 0.022 \mathrm{~kg}$ during the monsoon season followed by winter $(2.573 \pm 0.047 \mathrm{~kg})$ and summer season $(2.523 \pm 0.104 \mathrm{~kg})$ for 271,77 , and 25 kids born of the farm. The season had no significant effect on birth weight of kids. The higher birth weight during the monsoon season might be due to good quality forage available and more number of kidding than the other season. Present findings were conformed to the work of Raza et al., (1998), Baiden (2007), Thiruvenkadan et al., (2008), Bharthidhasan et al., (2009), Chandra et al., (2009), and Bhusan (2012). However, Salah et al., (1989), Paul et al., (1990), Elabid (2008), Benerjee and Jana (2010), Meel et al., (2010) also reported significant effect of season on birth weight of goat kids. This might be attributed to effect of large number of observations, period, environmental factors and nutrition supply.

\section{Effect of birth type on birth weight}

Table 1 revealed that the mean birth weight of single birth of kids and twin birth of kids was $2.689 \pm 0.042 \mathrm{~kg}$ and $2.407 \pm 0.064 \mathrm{~kg}$, 
respectively. The statistical analysis of data showed that type of birth had significant $(\mathrm{P}<0.05)$ effect on birth weight of kids. Banerjee and Jana (2010) also reported significant effect of type of birth on birth weights in Sirohi goat kids. Present findings is agreement to the reports of Tomar et al., (1997), Neeru and Kumar (2002), Elabid (2008), Thiruvenkadan et al., (2009),
Bharthidhasan et al., (2009), Chandra et al., (2009), Bhusan (2012), Hristova et al., (2013) and Hegan et al., (2014). Higher birth weight of single born kids was due to more nutrition available from the mother during prenatal period. Further there might be the limitation of space in the uterus for the growth of multiple kids during prenatal period.

Table.1 Effect-wise least square means of birth weight in mehsana kids

\begin{tabular}{|l|l|l|l|}
\hline Effect & N & Mean & SE \\
\hline Population mean & 373 & 2.548 & 0.043 \\
\hline Type of birth & & $* *$ & \\
\hline Single & 272 & 2.689 & 0.042 \\
\hline Twin & 101 & 2.407 & 0.064 \\
\hline Sex & & $* *$ & \\
\hline Male & 180 & 2.642 & 0.048 \\
\hline Female & 193 & 2.454 & 0.051 \\
\hline Season & & NS & \\
\hline Summer & 25 & 2.523 & 0.104 \\
\hline Monsoon & 271 & 2.604 & 0.022 \\
\hline Winter & 77 & 2.573 & 0.047 \\
\hline Year & & $* *$ & \\
\hline $\mathbf{2 0 1 1}$ & 96 & 2.508 & 0.069 \\
\hline $\mathbf{2 0 1 2}$ & 54 & 2.674 & 0.078 \\
\hline $\mathbf{2 0 1 3}$ & 43 & 2.741 & 0.086 \\
\hline $\mathbf{2 0 1 4}$ & 36 & 2.778 & 0.086 \\
\hline $\mathbf{2 0 1 5}$ & 30 & 2.338 & 0.085 \\
\hline $\mathbf{2 0 1 6}$ & 54 & 2.401 & 0.072 \\
\hline $\mathbf{2 0 1 7}$ & 60 & 2.394 & 0.077 \\
\hline
\end{tabular}

Mean in the same column with different superscripts differ significantly from each other ** indicate significant at $\mathrm{p}<0.05$ level and NS indicate non-significant.

\section{Effect of period on birth weight}

Year wise birth weight has increase trend from 2011 to 2014 then there was sudden decrease in average birth weight by $15.84 \%$ in year 2015. After that it remain almost constant. The effect of year was found significant $1 \%$ between the period several factors viz average rainfall, nutrition supply, disease outbreaks, breeding management and overall management of farm affect the birth weight of kids.

\section{References}

Anonymous 2017.District Wise Rainfall Figures Over Whole Gujarat 11 Th-17 Th-September 2017, India Meteorological Department Available At 
http://www.gujaratweather.com/wordpr ess/?page_id=15265 accessed on 7th august.2018.

Anonymous. 2012. 19th Livestock census 2012. Animal Husbandry Department, Government of India.

Baiden, Y.S. 2007. Birth weight birth type pre-weaning survivability of West African dwarf goat raised in the Dangme West District of the Greater Accra region of Ghana. Tropical Animal Health and Production. 39: 141147.

Banerjee, S. and Jana, D. 2010. Factors affecting birth weight of Sirohi goat kids reared in hot and humid climate of West Bengal. World Applied Sciences Journal. 9(12): 379-1382.

Bharathidhasan A, Rita Narayanan, Gopu P, Subramanian A, Prabakaran R and Rajendran R. 2009. Effect of nongenetic factors on birth weight, weaning weight and preweaning gain of Barbari goat. Tamilnadu Journal of Veterinary\& Animal Science. 5 (3): 99-103.

Bhusan, S. 2012. Effect of non- genetic factors on body weights of Jakhrana kids. Indian Journal of Small Ruminants. 18(2): 253-255.

Chandra, R., Karmkar, H.D., De, D., Kumar, S. and Rahman, H. 2009. Factor influencing birth weight of Sikkim local kids. Indian Journal of Small Ruminants. 15(1): 113-114.

Chawla, D.S., Nagpal, S. and Bhatnagar, D. S. 1984. Variation in body-weight gain of Beetal, Alpine and Saanen goats. Indian Journal of Animal Sciences. 54(7): 711 -714.

Duncan DB. 1955. Multiple range and multiple F tests. Biometrics 11: 1-42.

Elabid, E.H. 2008. Various factors affecting birth weight of Sudanese Nubian goat kids. Research Journal of Agriculture and Biological Sciences. 4(6): 700-703.

Hafez E.J.H. (1962). Reproduction in Farm
Animals. 5th edition. Lea and Febiger, Philadelphia, USA pp: 410-412.

Harikrishna, Ch., Raghunandan, T. and Gnana Prakash, M. 2013. Effect of season on kidding and birth weight in Osmanabadi goats reared in an organized farm, International Journal of Livestock Research. 3(2): 84-88.

Hegan, B.A., Nyameasem, J.K., AsafuAdjaye, A. and Duncan, J.L. 2014. Effects of non-genetic factors on the birth weight, litter size and pre-weaning survivability of West African Dwarf goats in the Accra Plains. Livestock Research for Rural Development. 26(1).138-142.

Hristova, T., Stoycheva, S., Zunev, P., Maslev, T. and Kovasevik, T. 2013. Non-genetic factors affecting birth weight of goat kids. Journal of Agricultural Science. 42(1): 21-25.

Jat, G.R., Datt, M., Bhateshwar, V. and Fogya, S. 2018. Factors Affecting Birth Weight in Sirohi Goat Kids. Int.J.Curr.Microbiol.App.Sci. 7(05): 2627-2631.

Meel, U.K., Nagda, R.K., Sharma S.K. and Rajawat, B.S. 2010.Growth performance of Sirohi goats under field conditions. Indian Journal of Small Ruminants.16(2): 246-248.

Neeru, D.S. and Kumar P. 2002. Factor affecting birth weight of kids in Indian goats. International Journal of Animal Sciences. 17: 57-60.

Paul, S., Sahu, B.B., Singh, D. and Rawat, P.S. 1990.Effect of season of birth, weaning age and concentrate supplementation on growth and chevon production. Indian Journal of Animal Production and Management. 6(4): 182186.

Rajendran. 2009. Effect of non-genetic factors on birth weight, weaning weight and preweaning gain of Barbari goat, TamilNadu Journal Veterinary Animal 
Science. 5, 99-103.

Raza, S.H., Tahir, M., Zia, S. Iqbal, A. and Shaqif, A. 1998.Impact of environmental factors on birth weight in Teddy goat. Asian Journal of Applied Sciences. 11(2): 152-154.

Roy, R., Prakash, B. and Khan, B.U. 1989. Genetic and non genetic sources of variation for growth of Jamunapuri kids. Indian Journal of Animal science. 59:874-877.

Salah, M.S., Bakkar M.N and Mogawer, H.H. 1989. Body weight of Aradi goat kids in Saudi Arabia at different ages and affecting factors. Journal of King Saud University. 1(1, 2): 17-24.

Sanchez, G.F.F. Montaldo, V.H. and Hdrez, L.A. 1994. Environmental and genetic effects on birth weight in graded-up goat kids. Canadian Journal of Animal Science. 74: 397-400.
Singh, P., Singh, M.K. and Singh, S.K. 2013.Effect of non-genetic factors on body weights of Jamunapari goats. Effect of non-genetic factors on body weights of Jamunapari goats. Indian Journal of Jammu. 19(2): 146-150.

Supakorn, C. and W. Pralomkarn. 2009. Estimation of Genetic Parameters on Pre-Weaning growth in Jamnapari kids. Indian J. Anim. Sci. 59: 874-877.

Thiruvenkadan, A.K., Chinnamani, K., Muralidharan, J. and Karunanithi, K. 2009. Factors affecting birth weight of Tellicherry kids. Indian Journal of Small Ruminants. 14(2): 255-258.

Tomar, A.K.S., Kumar, A. and Singh, N.P. 1997. Pattern of birth weight inheritance in Sirohi and Kutchi goat breed in semiarid condition of western India. Indian Journal of Small Ruminants. 3(1): 1-4.

\section{How to cite this article:}

Patel, J.V., A.K. Srivastava, H.D. Chauhan, J.P. Gupta, Y.M. Gami, V.K. Patel, M.P. Madhavatar and Thakkar, N.K. 2019. Factor Affecting Birth Weight of Mehsana Goat Kid at Organized Farm. Int.J.Curr.Microbiol.App.Sci. 8(03): 1963-1967.

doi: https://doi.org/10.20546/ijcmas.2019.803000 